\title{
GEODIVERSITY OF SURFACE KARST FEATURES OF GEOGRAPHICAL ZONES
}

\author{
RAZNOVRSTNOST KRAŠKIH POVRŠINSKIH RELIEFNIH OBLIK \\ NA KARBONATNEM KRASU
}

\author{
Márton VERESS ${ }^{1, *}$ \& Szilárd VETÉSI-FOITH ${ }^{2}$
}

\begin{abstract}
UDC 551.435.8:913(2)
Márton Veress \& Szilárd Vetési-Foith: Geodiversity of surface karst features of geographical zones

The diversity of small, medium, and large solution features of zonal karsts and high mountain karsts is described here. It was taken into consideration how diversity changes according to the distance from the Equator in case of small, medium and large features of various zonal karsts and how it varies based on the distance from altitude in case of the karren features (small features) of high mountain karsts. It can be established that the diversity of karst features decreases according to the distance from the Equator (independent of the size of the features), while in high mountains the diversity of karren features first increases with altitude and then it decreases. The decrease of the diversity of medium and large features moving away from the Equator can be explained by the decrease of dissolution intensity. The diversity change of karren features shows a relation with the diversity of the inclination of the bearing slope. Since on tropical karsts and in the medium elevated areas of high mountains (1600-2100 m) where bare slopes with large expansion and various slope inclination occur, the diversity of karren is great. On tropical karsts, slopes with diverse inclination were created by karstification and in high mountains by glacial erosion.

Keywords: zonal karst type, high mountain karst, small karst feature, medium karst feature, large karst feature, diversity.
\end{abstract}

\section{Izvleček \\ UDK 551.435.8:913(2) \\ Márton Veress \& Szilárd Vetési-Foith: Raznovrstnost kraških površinskih reliefnih oblik na karbonatnem krasu}

$\mathrm{V}$ prispevku je opisana raznovrstnost majhnih, srednjih in velikih korozijskih reliefnih oblik, $\mathrm{v}$ krasu različnih geografskih pasov in v visokogorskem krasu. Upoštevano je bilo, kako se raznovrstnost spreminja glede na oddaljenost od ekvatorja pri majhnih, srednjih in velikih reliefnih oblikah v različnih geografskih pasovih ter kako se spreminja glede na spreminjanje nadmorske višine pri škrapljah (drobne oblike) na visokogorskem krasu. Ugotoviti je mogoče, da se raznovrstnost kraških reliefnih oblik zmanjšuje glede na oddaljenost od ekvatorja (neodvisno od velikosti teh oblik), v visokogorju pa se raznovrstnost škrapelj $\mathrm{z}$ višanjem nadmorske višine sprva povečuje, nato pa se zmanjšuje. Zmanjševanje raznovrstnosti srednjih in velikih reliefnih oblik, značilno za čedalje večjo oddaljenost od ekvatorja, je mogoče pojasniti z zmanjševanjem intenzivnosti raztapljanja. Spreminjanje raznovrstnosti škrapelj pa kaže povezavo z raznovrstnostjo naklona pobočja, na katerem nastajajo. $\mathrm{Na}$ območjih tropskega krasa in na srednje visokih območjih visokogorja (1600-2100 m), kjer se pojavljajo obsežna gola pobočja $\mathrm{z}$ različnim naklonom pobočja, je raznovrstnost škrapelj zelo velika. Na tropskem krasu so pobočja $\mathrm{z}$ različnim naklonom nastala $\mathrm{z}$ zakrasevanjem, $\mathrm{v}$ visokogorju pa z ledeniško erozijo.

Ključne besede: kras geografskih pasov, visokogorski kras, majhna kraška reliefna oblika, srednja kraška reliefna oblika, velika kraška reliefna oblika, raznovrstnost.

\footnotetext{
${ }^{1}$ Department of Geography, Eötvös Lóránd University, 14 Rohonci út, HU-9700 Szombathely, Hungary,

E-mail: veress.marton@sek.elte.hu

${ }^{2}$ Department of Physical Geography, University of Pécs, 6/A Ifjúság út, HU-7624 Pécs, Hungary,

E-mail: szilard.vetesi@gmail.com

* Corresponding author
}

Received/Prejeto: 11. 5. 2021

DOI: https://doi.org/10.3986/ac.v50i2-3.10082 


\section{INTRODUCTION}

The aim of this study is to present the changes and the causes in the diversity of surface forms in the karsts of geographic zones and high mountains. The significance of geodiversity (Sharples, 1995; Kiernan, 1997; Gray, 2005), which is also contributed by the karst, is given by the fact that it is a precondition of the survival of biodiversity (Kevei Bárány, 2007). There have been studies on the description of geodiversity and on the classification of geosites for example in the Western Caucasus (Mikhailenko et al., 2020). Surface karst features are determinant, individual elements of karstic, often complex systems. The vulnerability of the karst, which influences biodiversity, depends on the density (BC Ministry of Forestry, 2003), type, and thus, on the geodiversity of surface karst features. The evaluation of geodiversity may give aspects and help to landscape and agricultural use.

Based on their characteristics, karst areas can be categorized as karst types. During researches various karst types have been distinguished and described (Grund, 1914; Cvijič 1918, 1925; Gvozdetskiy, 1965; Sweeting, 1973; Jakucs, 1977; Komatina, 1982; Balázs 1986,
1990; White, 1988). Karst types can be classified as zonal and azonal groups (Veress, 2020). Zonal karsts are climate dependent (e.g. tropical karst). Azonal karsts occur in the area of zonal karsts, but they are more or less independent due to any of their characteristics and may be present on any zonal karst (for example according to rock quality, karst can be of evaporate type or carbonate karst type under any climate).

The characteristics, features and processes (geomorphic agents) of a karst type are more or less different from those of another types. Geomorphic agents affecting feature development and thus, geodiversity in a karst area belonging to a karst type are dissolution (of cold water and warm water), precipitation, erosion (fluvial and glacial), biosphere, root effect, society, chemical weathering, mass movements, pluvial erosion, insolation, frost weathering and earthquakes. These are influenced by the characteristics of the karst such as the changes of the base level of erosion, vertical crust movements, solubility, the characteristics of dissolution residue, the characteristics of the karst surface, the karst water (its type, the posi-
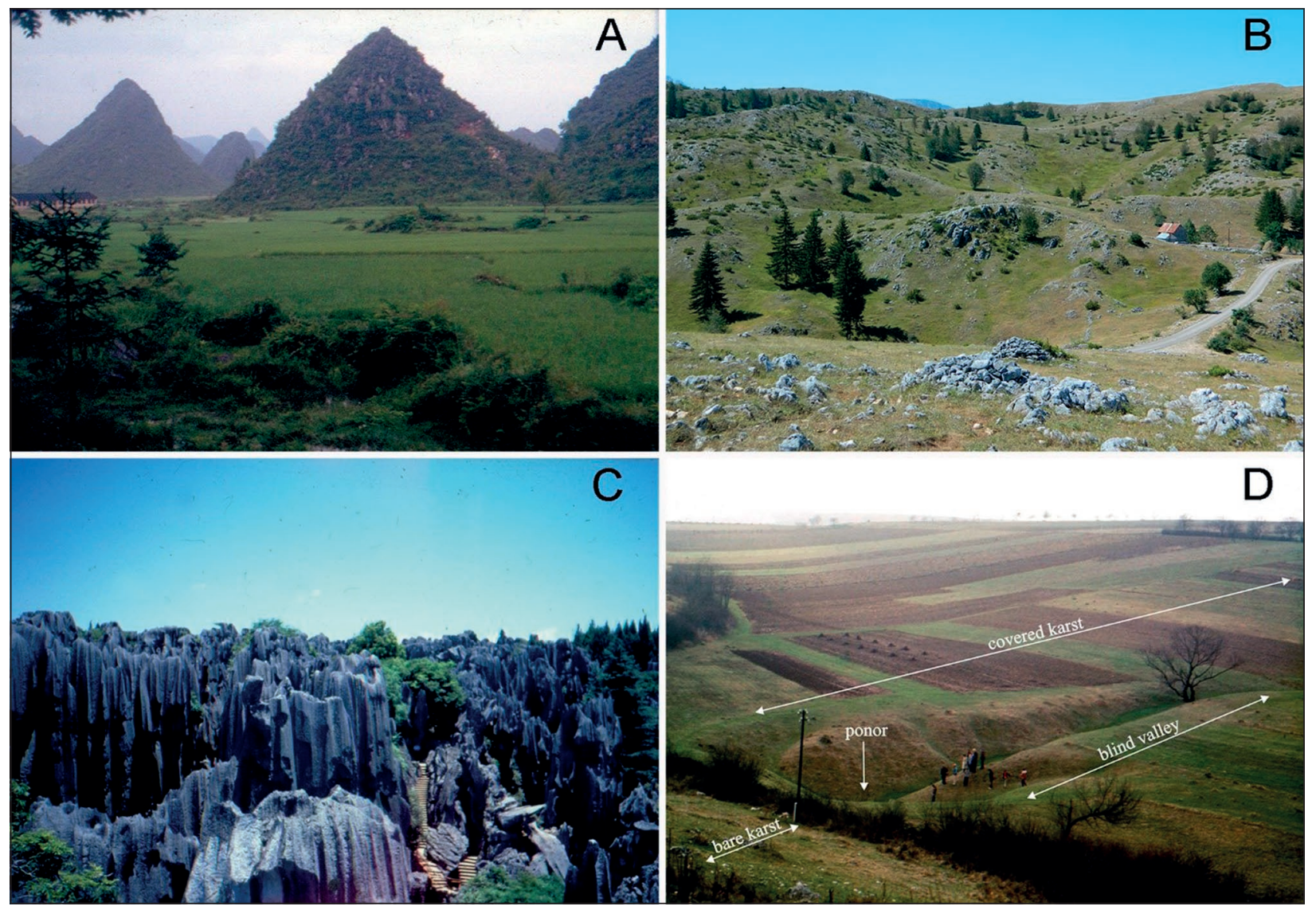

Figure 1: Medium and large surface karst features. A) fenglin karst (China), B) solution dolines, uvalas, karst hills (Durmitor, Montenegro), C) stone forest (Lunan, China), with wandkarren on the slopes of the towers, D) blind valley and ponor (Aggtelek Karst, Hungary). 
tion of the karstwater surface to the surface, the degree and frequency of its fluctuation), rock quality and rock structure, the current altitude of karst surface, precipitation (amount and distribution) and temperature, which also affect the evolution and the development of karst features. Some geomorphic agents are determinant in feature development (dissolution), while others have a complimentary role (root effect) or participate in feature development (mass movement). Some agents have a role in feature development only in some karst areas (warm water dissolution). The characteristics of the karst also have a different significance in feature development. For instance, solubility is an important factor, but vertical crust movement are less significant.

In the development of small features (karren features) the role of the effect of karst characteristics may be different than in case of other karst features and other characteristics may also become genetic and thus, geodiversity increasing factors. In case of karren formation, among the latter, vertical crust movements do not have a role at all, but rock quality and crust structure are more significant. Another characteristics may also play a role in the development of karren features, however not all types. Thus, mainly the development of features of flow origin (rillenkarren, rinnenkarren etc.) is affected by the expansion, inclination, and smoothness of the bearing slope through shaping water flow conditions (Veress, 2019).

At a given karst type or at a given belt in high mountains, the features can be predominant, supplementary and unique. Predominant features are always present and widespread, determining the face of the karst type (for example the karst inselberg on tropical karst). The supplementary feature is less widespread, it is not present in all karst areas of the type, in case of its lack, the karst type will not be different (for example poljes can be present or absent on fengcong). The appearance of unique features is incidental and there are only some present (e.g. gorges in the karst areas of some types). According to their size, surface features of karst areas and thus, of karst types can be small features (karren), medium features (e.g. solution dolines) and large features (e.g. poljes, intermountain plains). The width and depth of small features is below 1 meter, the diameter of medium features is between some metres and some hundreds of meters, while the diameter of large features is more than some hundred meters.
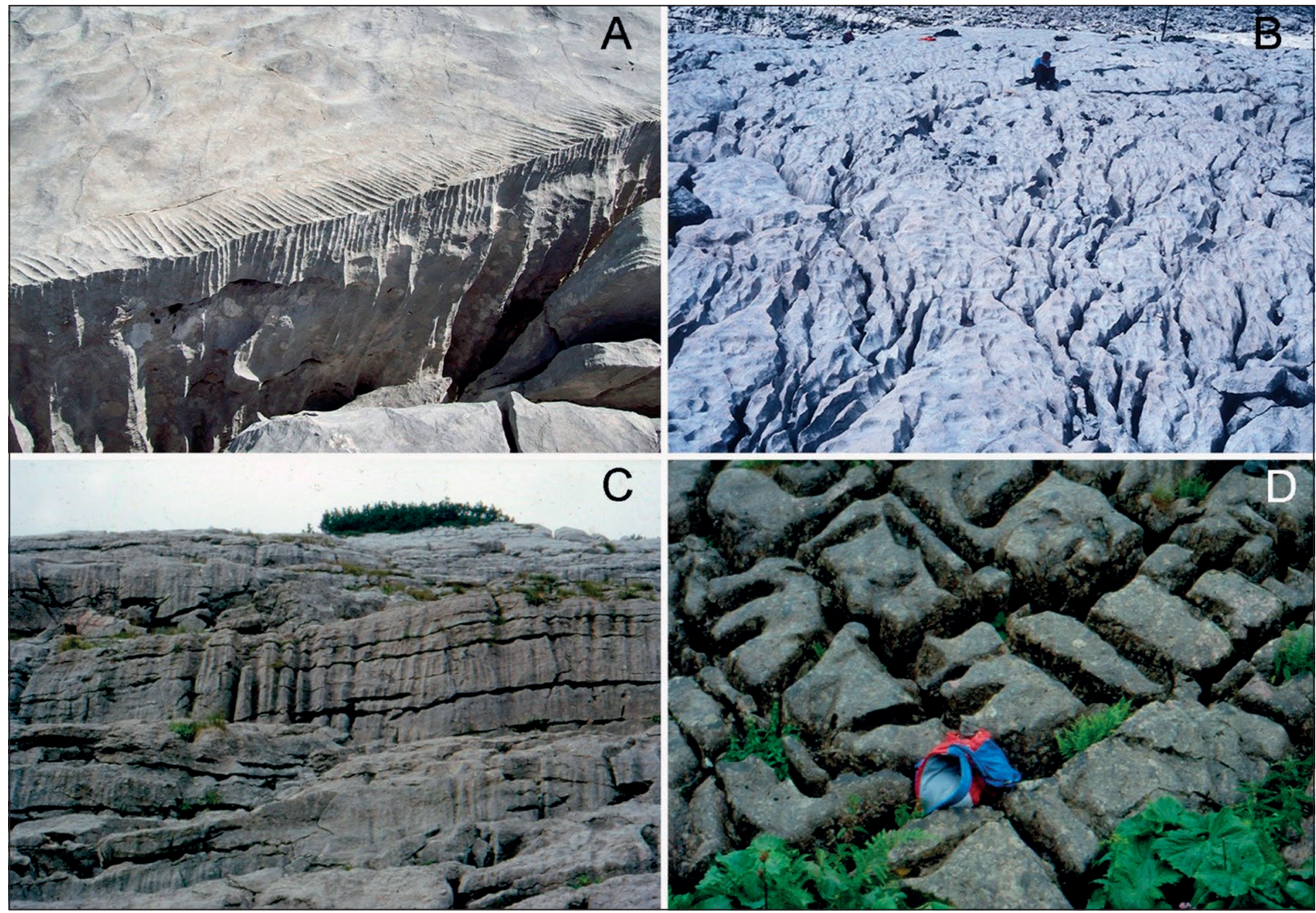

Figure 2: Karren features (Totes Gebirge, Austria). A) rillenkarren and wandkarren at the margin and on the wall of giant grike, B) rinnenkarren, rinnenkarren system and trittkarren, C) wandkarren and Schichtfugenkarren, D) grate karren. 


\section{METHOD}

Based on literary data (Wilford \& Wall, 1965; Williams, 1971, 1972a, 1972b, 1987; Sweeting, 1973; Balázs, 1986, 1990; White, 1988; Waltham \& Fookes, 2003; Veress, 2004, 2020; Ford \& Williams, 2007; Waltham, 2008; Andrejchuk et al., 2019) the medium and large surface features of zonal karst types (azonal carbonate karsts) with various climate and dissolution origin were distinguished without paleo features (Figure 1). Geomorphic agents of chosen zonal karst types were taken into consideration. We established and compared the feature diversity of these features of various zonal karst types and the number of geomorphic agents occurring there.

The diversity of the small features of these zonal karst types were also collected and compared based on literary data (Ginés, 2004, 2009; Veress et al., 2008).
Then, the diversity of small features of some high mountain karsts (based on examples of Alpine karst areas) in case of belts with various altitude were compared (Figure 2, based on Bögli, 1960, 1961, 1976; Veress, 2004, 2019). To show their altitudinal distribution we considered the karren feature type occurring along various sections and their density (Veress et al., 2006). Small features can be microkarren and mesokarren. Here, we mention that features larger than these thus, megakarren were classified as medium and large features (Ginés, 2009; Grimes, 2012), to which tropical karren, stone forest, tsingy and arête karst belong (Knez \& Slabe, 2009; Day \& Waltham, 2009; Williams, 2009; Veress, 2019; Veress et al., 2008). Micro karren and meso karren occur on the features of mega karren (Table 1) in great densities (Figure 1C).

Table 1: Solution and partly solution medium and large sized surface karst features and processes on zonal karst types (Wilford \& Wall 1965; Gvozdetskiy, 1965; Williams, 1971, 1972a, 1972b, 1977, Sweeting, 1973; White, 1988; Veress, 2004; Ford-Williams, 2007).

\begin{tabular}{|c|c|c|c|}
\hline Zonal karst type & Feature & $\begin{array}{l}\text { Occurrence on zonal subkarst } \\
\text { type, on azonal karst type and } \\
\text { feature }\end{array}$ & Geomorphic effect \\
\hline \multirow{15}{*}{ tropical, subtropical } & peak cluster (D) & fengcong & \multirow{15}{*}{$\begin{array}{l}\text { dissolution, dissolution } \\
\text { of thermal water origin, } \\
\text { precipitation, } \\
\text { biosphere, society, } \\
\text { root system, insolation, chemical } \\
\text { weathering, pluvial erosion } \\
\text { fluvial erosion, mass movements, } \\
\text { earthquakes }\end{array}$} \\
\hline & peak forest (D) & fenglin & \\
\hline & intermountain plain $(D, C)$ & fenglin & \\
\hline & tower (D) & stone forest & \\
\hline & ridge (D) & arête & \\
\hline & giant grike $(\mathrm{D})$ & tsingy & \\
\hline & karst hill $(\mathrm{T})$ & gufeng, intermountain plain & \\
\hline & polje (C) & fengcong & \\
\hline & solution dolines $(\mathrm{T})$ & fengcong & \\
\hline & uvala $(\mathrm{T})$ & fengcong & \\
\hline & cockpit doline (D) & cockpit karst & \\
\hline & shaft $(T)$ & fengcong & \\
\hline & blind valley $(\mathrm{T}, \mathrm{C})$ & mixed allogenic-autogenic & \\
\hline & ponor $(\mathrm{T}, \mathrm{C})$ & mixed allogenic-autogenic & \\
\hline & calcareous sinter (D) & valley, peak forest, peak cluster & \\
\hline \multirow{8}{*}{$\begin{array}{l}\text { medium belts } \\
\text { (temperate belt) }\end{array}$} & karst hill (T) & autogenic & \multirow{8}{*}{$\begin{array}{l}\text { dissolution, dissolution } \\
\text { of thermal water origin, } \\
\text { precipitation, biosphere, society, } \\
\text { root system, insolation, } \\
\text { frost weathering, chemical } \\
\text { weathering, } \\
\text { pluvial erosion, fluvial erosion, } \\
\text { snow erosion (E), glacial erosion } \\
\text { (E), } \\
\text { mass movements, earthquakes }\end{array}$} \\
\hline & polje $(T, C)$ & autogenic & \\
\hline & solution doline (D) & autogenic & \\
\hline & uvala (D) & autogenic & \\
\hline & shaft $(T)$ & autogenic & \\
\hline & blind valley $(\mathrm{T}, \mathrm{C})$ & mixed allogenic-autogenic & \\
\hline & ponor $(\mathrm{T}, \mathrm{C})$ & mixed allogenic-autogenic & \\
\hline & calcareous sinter $(\mathrm{T})$ & valley & \\
\hline \multirow{3}{*}{$\begin{array}{l}\text { taiga, tundra } \\
\text { (cold belt) }\end{array}$} & blind valley (D) & mixed allogenic-autogenic & \multirow{3}{*}{$\begin{array}{l}\text { dissolution, dissolution of } \\
\text { thermal water origin, frost } \\
\text { weathering, pluvial erosion, } \\
\text { fluvial erosion, mass movements, } \\
\text { snow erosion, glacial erosion (E), } \\
\text { earthquakes }\end{array}$} \\
\hline & ponor (D) & mixed allogenic-autogenic & \\
\hline & solution doline $(\mathrm{T})$ & valley floor & \\
\hline
\end{tabular}

D: dominant feature, T: tributary feature, E: earlier, C: complex development 


\section{RESULTS}

In Table 1 medium and large features of zonal karst types as well as geomorphic agents occurring in their area are described. It can be established that farther from the Equator the diversity of medium and large features of zonal karst types decreases (from 16 to 8 and then to 3 ), while the number of geomorphic agents first increases (from 12 to 15), and then decreases (to 9). In Tables 2 and 3 only the karren features (micro and meso karren) and the factors influencing karren formation are described. According to the data of the tables, the diversity of karren on zonal karst types shows a similar tendency (17, 9, 3 types of features) like in the case of medium and large features of the karst (Table

Table 2: Karren features and their development environment on zonal carbonate karsts (Veress, 2019; Veress et al., 2006; Veress et al., 2008).

\begin{tabular}{|c|c|c|c|c|c|}
\hline zonal karst & karren feature & $\begin{array}{l}\text { way of } \\
\text { dissolution }\end{array}$ & $\begin{array}{l}\text { occurrence on zonal } \\
\text { subkarst type, on azonal } \\
\text { karst type, feature }\end{array}$ & $\begin{array}{l}\text { development } \\
\text { environment }\end{array}$ & $\begin{array}{l}\text { slope angle } \\
\text { slope expansion }\end{array}$ \\
\hline \multirow{17}{*}{$\begin{array}{l}\text { tropical, } \\
\text { subtropical }\end{array}$} & rillenkarren (D) & 0 & fengcong, fenglin, IS, TS & +++ & $\begin{array}{l}\text { small, medium, } \\
\text { large }\end{array}$ \\
\hline & rinnenkarren (D) & ○ & fenglin, IS & +++ & medium, $\mathrm{L}$ \\
\hline & meanderkarren $(\mathrm{T})$ & O & TS & +++ & small, L \\
\hline & kamenitza (D) & $\mathbf{\square}$ & fenglin, fengcong, TS, IS & + & small, medium \\
\hline & wandkarren $(\mathrm{T})$ & O & SF, TS & +++ & large, L \\
\hline & grike(D) & $\mathbf{\square}$ & fengcong TS, SF & + & small, medium \\
\hline & pit (T) & $\square$ & TS, SF & + & small, medium \\
\hline & $\operatorname{notch}(\mathrm{T})$ & $\mathbf{\square}$ & fenglin, IL, TS & + & large \\
\hline & thimble karren $(\mathrm{T})$ & $\mathbf{\square}$ & TS, SF & +++ & small \\
\hline & root karren (D) & $\mathbf{\square}$ & fengcong, IL & ++ & small, medium \\
\hline & Karrennasen (D) & $\mathbf{\square}$ & fengcong, IL & ++ & small, medium, L \\
\hline & Schichtfugenkarren (T) & $\mathbf{\square}$ & fenglin, IS, SF, TS & $+\Delta$ & large, L \\
\hline & tunnel karren $(\mathrm{T})$ & $\mathbf{\square}$ & fengcong, IL & ++ & small \\
\hline & ripple $(T)$ & 0 & TS & +++ & large \\
\hline & scallops $(\mathrm{T})$ & O & TS & +++ & large \\
\hline & Spitzkarren (T) & $\Delta$ & TS & +++ & small \\
\hline & $\begin{array}{l}\text { korrosions hohlkehle } \\
\text { (T) }\end{array}$ & $\mathbf{a}$ & fengcong, IL & ++ & small, medium \\
\hline \multirow{10}{*}{$\begin{array}{l}\text { medium belts } \\
\text { (temperate belt) }\end{array}$} & rillenkarren $(\mathrm{T})$ & O & autogenic, RO & +++ & $\begin{array}{l}\text { small, medium, } \\
\text { large }\end{array}$ \\
\hline & kamnitza (D) & $\mathbf{\square}$ & autogenic, RO & + & small, medium \\
\hline & tunnel karren $(\mathrm{T})$ & $\mathbf{\square}$ & autogenic, RO & ++ & small \\
\hline & rootkarren(D) & $\mathbf{\square}$ & autogenic & ++ & small, medium \\
\hline & rainpits $(T)$ & $\mathbf{\square}$ & autogenic, RO & +++ & small \\
\hline & Karrennasen $(\mathrm{T})$ & $\mathbf{\square}$ & autogenic, RO & + & small, medium \\
\hline & grike (D) & $\mathbf{\square}$ & autogenic & + & small, medium \\
\hline & rinnenkarren $(T)$ ? & 0 & autogenic, RO & +++ & medium, L \\
\hline & pit (T) & $\mathbf{\square}$ & autogenic, RO & + & small, medium \\
\hline & $\operatorname{notch}(\mathrm{T})$ & $\mathbf{\square}$ & autogenic, RO & + & large \\
\hline \multirow{3}{*}{$\begin{array}{l}\text { tajga, tundra } \\
\text { (cold belt) }\end{array}$} & rillenkarren $(\mathrm{T})$ & 0 & autogenic, RO & +++ & medium, large \\
\hline & kamenitza $(\mathrm{T})$ & $\mathbf{\square}$ & autogenic, RO & +++ & small, medium \\
\hline & rinnenkarren $(T)$ & O & autogenic, RO & +++ & medium, L \\
\hline
\end{tabular}

D: dominant feature, T: tributary feature, $\boldsymbol{O}$ of flow origin, $\boldsymbol{\square}$ of percolation origin, $\boldsymbol{\Delta}$ remnant feature, $\Delta$ also affected by rock structure, IS: karst inselberg, SF: stone forest, TS: tsingy, IL: intermountain plain, RO: rock outcrop, + also subsoil, ++ only subsoil, +++ only on bare surface, L on expanded surface (larger than cca. 3-5 m), ? uncertain or very rare 
2). According to the data of Table 3 , the diversity of karren features shows a different tendency with the increase of altitude: the diversity of karren features first increases and then it decreases (below $1600 \mathrm{~m}$ there are 9 karren types, at an altitude of 1600-2100 $\mathrm{m}$ there are 20, and above 2100 m 2 karren types occur). However, in case of medium and large karst features, diversity decreases with altitude increase or some features are replaced by other particular features. Thus, below $1600 \mathrm{~m}$ poljes, blind valleys, ponors, giant grikes, shafts, typical solution dolines and uvalas oc- cur, above $1600 \mathrm{~m}$ giant grikes, shafts (their frequency increases), blind valleys and ponors can be found. Solution dolines are replaced by schachtdolines (Veress et al., 2019), and in the Alps small solution dolines with steep sides may also occur up to an altitude of 1800-1900 m (Veress, 2017). However, these features are not present above 2000-2200 $\mathrm{m}$. Giant dolines and uvalas of larger altitudes are features that developed in the interglacials when the bearing areas were still of lower position (Veress, 2017; Veress et al., 2019). This is proved by their past and present non-karstic

Table 3: Karren features in high mountains (based on data from the Julian Alps, Totes-Gebirge and Dachstein, Veress et al., 2006; Veress, 2010; Veress, 2019).

\begin{tabular}{|c|c|c|c|c|}
\hline Altitude $(\mathrm{m})$ & Karren feature & $\begin{array}{l}\text { Way of } \\
\text { dissolution }\end{array}$ & development environment & $\begin{array}{l}\text { slope angle, expansion } \\
\text { of surface }\end{array}$ \\
\hline \multirow{9}{*}{$\begin{array}{l}\text { below } 1600 \\
\text { (temperate, fluvial } \\
\text { erosional belt, solution } \\
\text { sub belt) }\end{array}$} & thimble karren(T) & $\mathbf{\square}$ &,$+++ \mathrm{RO}$ & small \\
\hline & $\operatorname{notch}(T)$ & $\mathbf{\square}$ & + & large \\
\hline & rootkarren (D) & $\square$ & ++ & small, medium \\
\hline & grike (D) & $\mathbf{\square}$ & + & small \\
\hline & kamenitza (D) & $\mathbf{\square}$ & + & small, medium \\
\hline & rillenkarren $(\mathrm{T})$ & 0 &,$+++ \mathrm{RO}$ & small, medium, large \\
\hline & bedding-head karren $(\mathrm{T})$ & $\mathbf{\square}$ &,$+ \Delta$ & medium, large \\
\hline & Karrennasen (D) & $\square$ & + & small, medium \\
\hline & korrosionshohlkehle (T) & $\mathbf{\square}$ & ++ & small, medium \\
\hline \multirow{20}{*}{$\begin{array}{l}1600-2100 \\
\text { (periglacial belt) }\end{array}$} & $\operatorname{notch}(\mathrm{T})$ & $\mathbf{\square}$ & + & large \\
\hline & grike (D) & $\square$ & + & small, medium \\
\hline & grate karren $(\mathrm{T})$ & $\mathbf{\square}$ & + & small \\
\hline & kamenitza $(\mathrm{T})$ & $\mathbf{\square}$ & + & small, medium \\
\hline & tunnel karren $(T)$ & $\mathbf{\square}$ & ++ & small \\
\hline & karren cave $(\mathrm{T})$ & 0 & +++ & small, L \\
\hline & pit (T) & $\mathbf{\square}$ & +++ & small, medium \\
\hline & rillenkarren (D) & 0 & +++ & small, medium, large \\
\hline & rinnenkarren (D) & 0 & +++ & medium, L \\
\hline & round karren $(\mathrm{T})$ & $0, \square$ & + & medium, L \\
\hline & meanderkarren $(\mathrm{T})$ & 0 & +++ & small, L \\
\hline & trittkarren $(\mathrm{T})$ & 0 & +++ & small, medium \\
\hline & wandkarren (D) & 0 & +++ & large, $\mathrm{L}$ \\
\hline & ripple $(\mathrm{T})$ & 0 & +++ & large \\
\hline & scallops $(\mathrm{T})$ & 0 & +++ & large \\
\hline & rainpits $(T)$ & $\mathbf{\square}$ & +++ & small \\
\hline & Schichtfugenkarren $(\mathrm{T})$ & $\mathbf{\square}$ &,$+++ \Delta$ & large, $\mathrm{L}$ \\
\hline & Spitzkarren (T) & $\Delta$ & +++ & small \\
\hline & karren table $(\mathrm{T})$ & $\Delta$ & +++ & small, L \\
\hline & Karennasen $(T)$ & $\mathbf{\square}$ & + & small, medium \\
\hline \multirow{2}{*}{$\begin{array}{l}\text { above } 2100 \mathrm{~m} \\
\text { (glacial belt) }\end{array}$} & rillenkarren $(T)$ & 0 & +++ & small, medium, large \\
\hline & wandkarren $(\mathrm{T})$ & 0 & +++ & large, $\mathrm{L}$ \\
\hline
\end{tabular}

D: dominant feature, T: tributary feature, $\boldsymbol{\square}$ of percolation origin, $\boldsymbol{O}$ of flow origin, $\boldsymbol{\Delta}$ remnant feature, $\Delta$ rock structure also affects, + also subsoil, ++ only subsoil, +++ only on bare surface, slope angle: small (below $\left.10^{\circ}\right)$, medium $\left(10^{\circ}-60^{\circ}\right)$, large $\left(\right.$ above $\left.60^{\circ}\right), \mathrm{L}$ on expanded surface (larger than cca. 3-5 m) 
development, however karstification is present in their area which is indicated by karren, ponors and subsidence dolines (Djurovič et al., 2010; Veress et al., 2019), they are polygenetic features transformed by non-karstic processes (glacial erosion, frost weathering, mass movements, Ford, 1984, Djurovič et al., 2010).

\section{DISCUSSION}

Since under temperate climate, the diversity of medium and large karst features is lower than in the tropical belt despite a greater number of geomorphic agents, the increase of the diversity of features towards the Equator is caused by the increase of dissolution intensity. (Dissolution and its intensity overwrite the effect of other geomorphic agents at landscape evolution.) Dissolution intensity is greater and greater towards to the Equator as a result of the increase of biogenic $\mathrm{CO}_{2}$ production (Jakucs, 1977; Trudgill, 1985; Zámbó, 1986). Thus, the greater the dissolution intensity, the greater the diversity of medium and large features and the closer the relation between dissolution and feature diversity. In case of low dissolution intensity, some features do not develop at all, or if they do, they occur rarely and only with a small size, while high dissolution intensity favours feature development as well as their great density and size which favourably enable feature coalescence and thus, newer and newer features can develop. This is characteristic of tropical karsts. However, in addition to high dissolution intensity, long-lasting, constant dissolution conditions also contributed to large feature diversity in the tropical belt. Karstification has been taking place on the majority of tropical karsts under constant climate and tectonic calm for several million or ten million years. All this favoured the development of larger and larger and more and more complex features from initial depressions and thus, feature diversity may have increased as a result of this as well. In high mountains, the decreasing geodiversity (or feature change) of medium and large features with the growth of altitude can also be explained by the decrease of dissolution intensity (Veress, 2017).

The fact that geodiversity changes differently at small features during moving farther from the Equator and the sea level can be explained by the role of one type of dissolution. Karst features can develop by direct and indirect dissolution. Karren features develop by direct dissolution taking place on rock surfaces (Bögli, 1960, 1976; Ginés, 2009), when the feature develops during dissolution occurring on the rock surface. However, medium and large karst features such as solution dolines, poljes, karst inselbergs etc. are formed by indirect, complex dissolution (Sweeting, 1973; Gams, 1978; Williams, 1983, 1985, 2004; Ford \& Williams, 2007;
Waltham, 2008). During direct dissolution, dissolution does not only affect the surface. Thus, during the development of solution dolines, superficial dissolution and dissolution taking place in the epikarst have a joint effect, strengthening each other (Williams, 1983). This relation is not present at the development of karren even if dissolution happens in the epikarst (for example at tunnel karren).

The development and thus, the diversity of karren is determined by surface conditions affecting direct dissolution and only partly by dissolution intensity. The high diversity of karren is caused by the dissectedness of the surface since slopes of various expansion and inclination frequently occur adjacent to each other as a result of the high dissectedness of the surface. Different karren features may develop on slopes with various expansion and inclination (Veress, 2019). Slopes with a larger inclination either on tropical karst or in high mountains and at a higher altitude in high mountains are bare with a greater possibility in case of any slope inclination. This has a more significant contribution to the diversity increase of karren features (various karren features of flow origin develop). Such surfaces can be found in the tropical belt and in high mountains (on glaciokarsts). At the former sites, the development of steep, bare slopes with various inclination is caused by karstification itself. However, in high mountains, the reason for it are intensive and manifold geomorphic agents (e.g. fluvial erosion, mass movements), but mostly glacial erosion being predominant during the glacials. However, it is also contributed by karstification here and within this karren formation thus, for example ripples and scallops develop on the steep side walls of rinnenkarren. Glacial erosion not only created slopes with various inclination, but also smooth surfaces favouring water flow. Here, diversity can also be increased by the long-lasting dissolution caused by snow melt. However, it is without doubt that the low karren feature diversity of areas above $2100 \mathrm{~m}$ is contributed by the short snow-free period, the short ice free geomorphic evolution and the dominance of other processes (e.g. mass movements or snow erosion destroy karren features here) too. 


\section{CONCLUSIONS}

The diversity of small, medium, and large surface karst features in the karst areas of various karst types can be interpreted by considering the intensity and type of dissolution. Dissolution intensity, through direct dissolution which is a type of dissolution primarily affects the diversity of medium and large features, while the other type of dissolution, indirect dissolution influences the diversity of small features (karren features). Bare slopes with various expansion and inclination favour direct dissolu- tion. This is the consequence of intensive karstification on their development on tropical karsts and of glacial erosion on high mountain karsts. While the diversity of medium and large karren features and thus, indirect dissolution through $\mathrm{CO}_{2}$ production is climate dependent, the diversity of small features depends more on factors influencing direct dissolution (slope angle, slope expansion, the quality of the slope surface).

\section{REFERENCES}

Andrejchouk, V., Blachowicz, T., Dluzewski, M., 2019. Fractal analysis of tropical karst relief - South China Karst case study. Geological Quarterly, 63(4): 729740 .

Balázs, D., 1986. Kína karsztvidékei (Karst regions of China). Karszt és Barlang, II: 87-92. (in Hungarian)

Balázs, D., 1990. A dél-kínai karsztvidék föbb barlangtípusai (Main cave types of the South-China karst region). Karszt és Barlang, I: 53-60. (in Hungarian)

BC Ministry of Forestry, 2003. Karst Inventory Standards and Vulnerability Assessment Procedures for British Columbia. Version 2.0. https://www2.gov.bc.ca/ gov/content/environment/natural-resource-stewardship/laws-policies-standards-guidance/inventory-standards [Accessed 20 March 2021].

Bögli, A., 1960. Kalklösung und Karrenbildung. Zeitschrift für Geomorphologie, 2: 4-21.

Bögli, A., 1961. Karrentische, ein Beitrug zur Karstmorphologie. Zeitschrift für Geomorphologie, 5: 185193.

Bögli, A., 1976. Die wichtigsten Karrenformen der Kalkalpen. Karst processes and relevant landforms. International Speleological Union, Commission on Karst denudation, Department of Geography, Philosophical Faculty, University of Ljubljana, Ljubljana, pp. 141-149.

Cvijič, J., 1918. Hydrographie souterraine et evolution morphologique du karst. Revue de Geographie Alpine, 6(4): 375-426.

Cvijič, J., 1925. Types morphologiques des terrains calcaires. Comptes rendus de l'Académie des Sciences, 180: 592-757.

Day, M., Waltham, T., 2009. The pinnacle karrenfields of Mulu. In: Ginés, A., Knez, M., Slabe, T, Dreybrodt, W. (Eds.), Karst Rock Features - Karren Sculpturing.
Carsologica 9. Založba ZRC. Institut za raziskovanje krasa ZRC SAZU, Postojna, pp. 423-432.

Djurović, P., Petrović, A.S., Simić, S., 2010. The overall impact of Pleistocene glaciation on morphological diversity of uvalas at Durmitor and Žijovo. Bulletin of the Serbian Geographical Society, 90: 17-34. https://doi.org/10.2298/GSGD1001017D

Ford, D.C., Williams, P.W., 2007. Karst Hydrogeology and Geomorphology. John Wiley \& Sons, Ltd., Chichester, 562 pp.

Gams, I., 1978. The polje: The problem of definition. Zeitschrift für Geomorphologie, 22: 170-181.

Ginés, A., 2004. Karren. In: Gunn, J. (Ed.), Encyclopedia of Caves and Karst Science. Fitzroy Dearborn, New York, London, pp. 470-473.

Ginés, Á., 2009. Karrenfield landscapes and karren landforms. In: Ginés, Á., Knez, M., Slabe, T., Dreybrodt, W. (Eds.), Karst rock features - Karren sculpturing. Carsologica 9. Založba ZRC. Inštitut za raziskovanje krasa ZRC SAZU, Postojna-Ljubljana, pp. 13-24

Gray, M., 2005. Geodiversity and Geoconservation: What? Why, and How?. Parks Stewardship Forum, 22(3): 4-12.

Grimes, K.G., 2012. Surface Karst Features of the Judbarra/Gregory National Park, Northern Territory, Australia. Helectite, 41: 15-36

Grund, A., 1914. Die geographische Zyklus im karst. Zeitschrift der Gesellschaft für Erdkunde, 52: 621640 .

Gvozdetskiy, N.A., 1965. Types of Karst in the U.S.S.R. Separatum, Problems of Speleological Research, 4754.

Jakucs, L., 1977. Morphogenetics of Karst Regions. Adam Hilgar, Bristol, pp. 284.

Kevei Bárány, I., 2007. Geodiverzitás a karsztokon (Geo- 
diversity on karsts). Karsztfejlődés XII: 215-223. (in Hungarian)

Kiernan, K., 1997. Landform classification for geoconservation. In: Eberhard, R., (Ed.), Pattern and Process: Towards a Regional Approach to National Estate Assessment of Geodiversity. Technical Series No. 2. Australian Heritage Commission \& Environment Forest Taskforce, Environment Australia, Canberra, pp. 21-34.

Knez, M., Slabe, T., 2009. Lithological characteristics shape, and rock relief of the Lunan stone forests. In: Ginés, A., Knez, M., Slabe, T., Dreybroot, W. (Eds.), Karst Rock Features - Karren Sculpturing. Carsologica 9. Založba ZRC, Inštitut za raziskovanje krasa ZRC SAZU, Postojna, pp. 439-452.

Komatina, M., 1982. A fejlődés feltételei és a karsztos területek felosztása (Conditions of evolution and classification of karst areas) In: Burger, A., Dubertret, L. (Eds.), Karsztterületek hidrogeológiája, MKBT, Budapest, pp. 23-35. (in Hungarian)

Mikhailenko, A.V., Ruban, D.A., Ermolaev, V.A., 2020. The Khadzhokh Canyon System - An Important Geosite of the Western Caucasus. Geosciences, 10(5): 181. https://doi.org/10.3390/geosciences10050181

Sharples, C., 1995. Geoconservation in forest management - principles and procedures. Tasforests, 7: 3750.

Sweeting, M.M., 1973. Karst Landforms. Columbia University Press, New York, 362 pp.

Trudgill, S.T., 1985. Limestone geomorphology. Longman, New York, 196 pp.

Veress, M., 2004. A karszt (The Karst) - BDF. Természetföldrajzi Tanszék, Szombathely, 215 pp. (in Hungarian)

Veress, M., 2010. Karst Environments, Karren Formation in High Mountains. Springer, Dordrecht, Heidelberg, London, New York, 230 pp.

Veress, M., 2017. Solution doline development on glaciokarst in alpine and Dinaric areas. Earth Science Reviews, 173: 31-48.

Veress, M., 2019. Karren and karren formation of bare slopes. Earth Science Reviews, 188: 279-290. https:// doi.org/10.1016/J.EARSCIREV.2018.11.006

Veress, M., 2020. Karst Types and Their Karstification. Journal of Earth Science, 31(3): 621-634. https://doi. org/10.1007/s12583-020-1306-x

Veress, M., Tóth, G., Zentai, Z., Kovács, Gy., 2006. A magashegységi karrosodás mértékének és minőségének alakulása a különbözö növényövekben (Degree and quality of high mountain karren formation in different vegetation belts). Karszt és Barlang: 39-48. (in Hungarian)

Veress, M., Lóczy, D., Zentai, Z., Tóth, G., Schläffer, R.,
2008. The origin of the Bemaraha tsingy (Madagascar). International Journal of Speleology, 37(2): 131-142.

Veress, M., Telbisz, T., Tóth, G., Lóczy, D., Ruban, D.A., Gutak, J.M., 2019. Glaciokarst. Springer Geography, Cham, 516 pp. https://doi.org/10.1007/978-3-31997292-3

Waltham, T., 2008. Fencong, fenglin, cone karst and tower karst. Cave and Karst Science, 35(3): 77-88.

Waltham, A.C., Fookes, P.G., 2003. Engineering classification of karst ground conditions. Quarterly Journal of Engineering Geology and Hydrogeology, 36: 101-118.

White, W.B., 1988. Geomorphology and Hydrology of Karst Terrains. Oxford University Press, New York - Oxford, 464 pp.

Wilford, G.E., Wall, J.R.D., 1965. Karst topography in Sarawak. Journal of Tropical Geography, 21: 44-77.

Williams, P.W., 1971. Illustrating morphometric analysis of karst with examples from New Guinea. Zeits für Geomorphologie, 15(1): 40-61.

Williams, P.W., 1972a. Morphometric analysis of polygonal karst in New Guinea. Geological Society of America Bulletin, 83: 761-796.

Williams, P.W., 1972b. The analysis of spatial characteristics of karst terrains. In: Chorley, R.J. (Ed.), Spatial Analysis in Geomorphology. Methuen, London pp. 136-163.

Williams, P.W., 1983. The role of the subcutaneous zone in karst hydrology. Journal of Hidrology, 61: 45-67.

Williams, P.W., 1985. Subcutaneous hydrology and the development of doline and cockpit karst. Zeitschrift für Geomorphologie, 29(4): 463-482.

Williams, P.W., 1987. Geomorphic inheritance and the development of tower karst. Earth Surface Processes and Landforms, 12(5): 453-465. https://doi. org/10.1002/esp.3290120503

Williams, P.W., 2004. Dolines. In: Gunn, J. (Ed.), Encyclopedia of Caves and Karst Science. Fitzroy Dearborn, New York, London, pp. 304-310.

Williams, P.W., 2009. Arête and pinnacle karst of Mount Kaijende. In: Ginés, A., Knez, M., Slabe, T., Dreybrodt, W. (Eds.), Karst Rock Features - Karren Sculpturing. Carsologica 9. Založba ZRC, Inštitut za raziskovanje krasa ZRC SAZU, Postojna, pp. 433437.

Zámbó, L., 1986. Karsztvörösagyagok $\mathrm{CO}_{2}$ termelés és a karsztkorrózió összefüggése (The connection between the $\mathrm{CO}_{2}$ production of karst red clays and karst corrosion). A Nehézipari Müszaki Egyetem Közleményei I. sorozat Bányászat, 33(1-4): 125-138. (in Hungarian) 